\title{
The nZEB Requirements for Residential Buildings: An Analysis of Thermal Comfort and Actual Energy Needs in Portuguese Climate
}

\author{
Jaime Resende (D) and Helena Corvacho* (D) \\ CONSTRUCT (LFC), Faculty of Engineering (FEUP), University of Porto, 4200-465 Porto, Portugal; \\ jaime.resende@fe.up.pt \\ * Correspondence: corvacho@fe.up.pt
}

check for updates

Citation: Resende, J.; Corvacho, $\mathrm{H}$. The nZEB Requirements for Residential Buildings: An Analysis of Thermal Comfort and Actual Energy Needs in Portuguese Climate. Sustainability 2021, 13, 8277. https:// doi.org/10.3390/su13158277

Academic Editor: Antonio Caggiano

Received: 22 May 2021

Accepted: 19 July 2021

Published: 24 July 2021

Publisher's Note: MDPI stays neutral with regard to jurisdictional claims in published maps and institutional affiliations.

Copyright: (c) 2021 by the authors. Licensee MDPI, Basel, Switzerland. This article is an open access article distributed under the terms and conditions of the Creative Commons Attribution (CC BY) license (https:// creativecommons.org/licenses/by/ $4.0 /)$.

\begin{abstract}
As of now, in the EU, all new buildings will have to comply with the requirements for nearly zero energy buildings (nZEB). Portugal defines limits for the maximum useful energy needs for heating and for the maximum primary energy needs and establishes that $50 \%$ of primary energy needs must be covered by local renewable energy sources, based on the dwellings' nominal condition of use. However, the actual use is different. Thus, a simulation tool is used to assess thermal comfort and energy needs for different conditions of use of a dwelling complying with nZEB requirements. Eight different locations are chosen, covering all Portuguese climate zones. The nZEB requirements lead to unusually high levels of thermal insulation, especially in the coldest regions, so special care must be taken by the designers to avoid overheating in summer. Without using HVAC system, some discomfort is found but comfort is possible with low energy consumption. Furthermore, the compliance with nZEB requirements proved to be enough to ensure that a significant percentage of useful energy needs for heating, cooling and domestic hot water is supplied by local renewable energy sources. This is key in order to overcome the high rate of energy poverty in Portugal.
\end{abstract}

Keywords: nZEB requirements; conditions of use; thermal comfort; energy needs; renewable energy

\section{Introduction}

The European Union (EU) introduced the concept of nearly zero energy buildings (nZEB) a decade ago as a way to decarbonize the building stock, which is responsible for $40 \%$ of total energy consumption and for 36\% of greenhouse gas (GHG) emissions [1,2].

The construction sector, as a major contributor of negative environmental impacts, must therefore be the object of particular attention. The strategies to achieve the goal of a radical reduction of GHG emissions include applying energy and environmental standards and policies, conducting impact assessments, adopting low-carbon technologies, and reducing the energy consumption in buildings [3] in all phases of their life cycle.

The Energy Performance of Buildings Directive (EPBD) in its recast of 2010 established that all new buildings constructed in the EU from January 2021 onwards must be nZEB. This concept was defined as "a building that has a very high energy performance" and in which "the nearly zero or very low amount of energy required should be covered to a very significant extent by energy from renewable sources, including energy from renewable sources produced on-site or nearby". Its practical application is the responsibility of each Member State which should define the requirements for a "very high energy performance" and what would be the recommended significant contribution of "energy from renewable sources" [1].

Establishing a single level of nZEB target requirement for the whole of Europe is neither possible nor feasible due to the influence of regional climate conditions on heating and cooling needs and the cost-effectiveness of energy efficiency measures and renewable energy packages. In scenarios where a numerical indicator has already been defined, 
requirements vary widely from $0 \mathrm{kWh} /\left(\mathrm{m}^{2}\right.$ year) to $270 \mathrm{kWh} /\left(\mathrm{m}^{2}\right.$ year). In residential buildings, most Member States aim to achieve a level of primary energy use not exceeding $50 \mathrm{kWh} /\left(\mathrm{m}^{2}\right.$ year $)[4]$.

The application of the nZEB concept is at different stages, depending on the region, since different Member States face different challenges. Northern European countries already have an advanced application experience, due to their overriding need to manage cold climates and their focus is on controlling heating energy needs and consumption. In southern European countries, with high temperatures and high solar irradiance in summer, most buildings have to reach a compromise between heating and cooling energy needs. Thus, it is necessary to resolve potential conflicts between winter and summer comfort requirements [5].

The two most significant energy uses in European residential sector are heating and domestic hot water (DHW). However, there are great differences between the regions. Northern countries consume twice as much energy with these services as southern countries. Although consumption is still high, rates have decreased over the years, thanks to energy policies $[5,6]$.

On the other hand, the energy for cooling demand is growing faster than any other end-use in buildings. Its numbers more than tripled between 1990 and 2016 becoming one of the most critical factors that puts the most stress on several countries energy systems and increases carbon emissions. Besides, there is no or little doubt that the global demand for cooling will continue to grow in the coming decades due to global warming. According to a baseline scenario, the cooling energy needs could triple by 2050 . This means that measures to improve buildings energy performance will be of more crucial importance in the long run [7].

In general, European nZEB guidelines are more concerned with cold weather conditions. Bioclimatic strategies should be reevaluated to integrate recommendations for heating and cooling seasons for new and refurbishment nZEB projects [8]. In southern Europe, this is even more important. The prevention of overheating in buildings during the summer is crucial and the amount of solar radiation transmitted through the building's glazing must be controlled [9].

A significant and concerning anomaly found in the context of thermal comfort in dwellings is that southern European countries, which have a milder climate and greater solar radiation availability, are those with the worst indoor thermal comfort conditions due to their high energy poverty rates [10].

Decree-Law No. 118/2013 [11], that transposed the Directive 2010/31/EU into Portuguese national regulation, introduced the nZEB concept, adopting the exact definition of the Directive, and making them mandatory from January 2021. That decree-law was complemented by several ordinances, such as Ordinance No. 349B/2013 [12] that defined the requirements to comply with the decree-law and the respective calculation method. Buildings have to comply with a maximum allowable value of annual nominal needs of primary energy $\left(\mathrm{N}_{\mathrm{t}}\right)$, which takes into consideration the maximum allowable values of the annual nominal needs of useful energy for heating $\left(\mathrm{N}_{\mathrm{i}}\right)$ and for cooling $\left(\mathrm{N}_{\mathrm{v}}\right)$, in addition to the useful energy needed for DHW.

Six years later, Ordinance No. 98/2019 [13] detailed the nZEB requirements for dwellings, which are: an annual nominal needs of useful energy for heating $\left(\mathrm{N}_{\mathrm{ic}}\right)$ equal to or less than $75 \%$ of its maximum allowable value $\left(\mathrm{N}_{\mathrm{i}}\right)$; an annual nominal needs of primary energy $\left(\mathrm{N}_{\mathrm{tc}}\right)$ equal to or less than $50 \%$ of its maximum allowable value $\left(\mathrm{N}_{\mathrm{t}}\right)$; and the use of local renewable energy systems able to cover at least $50 \%$ of annual primary energy needs.

The maximum allowable values of heating useful energy needs and primary energy needs are established by the regulation based on reference values of thermal parameters and reference conditions applied to the geometry of the building under analysis. Therefore, there is no fixed threshold for energy needs applicable to all buildings.

It is possible to optimize energy consumption in buildings through the appropriate and holistic use of modelling and simulation tools in the design phase, allowing for a better 
choice of the building envelope and the technical systems. So, the use of control strategies for HVAC systems fueled by renewable energy contributes to effectively achieving considerable energy savings and reducing $\mathrm{CO}_{2}$ emissions [14]. Notable technological advances made in recent years have provided modelling and simulation tools with acceptable accuracy.

A holistic treatment is desirable, namely, a multidisciplinary approach that takes into account different areas of action (architectural solutions, development of innovative insulation materials, improvements in the level of engineering, economic viability and others), to facilitate the achievement of the objective of improving the energy efficiency of buildings [14].

Bearing in mind that the EPBD recast allows several interpretations concerning the numerical limits or ranges for the definition of nZEB requirements, each Member States choices can and should be justified by variable factors such as specific climatic conditions, local goals, cultural user behavior and local construction traditions. Southern European countries have both heating and cooling needs due to their climate, making it more difficult to find some balance through passive strategies. Besides, Portugal has one of the highest levels of energy poverty in the EU, which may sound surprising due to its less demanding mild climate and consequent lower energy needs for heating.

It is undeniable that a high percentage of Portuguese families cannot afford to have a high energy consumption. The price of energy for households in Portugal is one of the highest in Europe, especially when expressed in purchasing power standards. A massive adoption of systems for the local use of available renewable sources, mainly solar, will certainly help to overcome this problem. The energy poverty that affects a significant part of the population can and must be solved in an eco-friendly way. Some local authorities that manage social housing neighborhoods are starting these initiatives, planning to install solar collectors and solar PV panels centrally managed in order to get the most out of them, lowering energy bills and improving comfort with no costs for the tenants.

Thermal solar collectors for DHW were already made mandatory in all new buildings, in 2006. The Decree-Law No. 118/2013 [11] and related regulatory documents allowed the choice of any other renewable energy system as long as it provides the same amount of renewable energy as an estimated number of standard solar collectors. As previously stated, now the new nZEB requirements [13] go further and demand that the installed systems cover at least $50 \%$ of the primary energy needs of the household.

Another question that must be addressed is the fact that regulatory requirements are based on nominal conditions of use which are often very far from the real conditions. Regulation considers that the heating system is on $24 \mathrm{~h}$ a day, throughout the whole heating season. The same is considered for the cooling system in summer. In function of these considerations, the regulation establishes several requirements, namely the minimum level of thermal insulation of the building envelope. However, because of energy poverty, intrinsic life habits and, obviously, because of the mildness of the climate, almost no households work in those nominal conditions. Many of them do not use heating at all or just very occasionally and the great majority do not have an installed cooling system. This means that it is very important to evaluate the implications of regulatory requirements not only in terms of energy consumption but also in terms of thermal comfort. If a high level of thermal insulation is always beneficial in winter for a building where no active heating is provided, that is not always the case in summer, when a higher level of insulation can cause overheating. In addition, an unrealistic estimation of energy needs may lead to an oversizing of technical systems, which is definitely neither energy efficient nor economically sensible. In the process of transposing the EU Directive 2018/844 [2] into the national regulation, it was already announced that a new calculation methodology would be established by the end of June 2021. It is foreseeable that dynamic simulation will be made mandatory.

The main goal of the work presented in this paper is to evaluate the impact of nZEB requirements on the performance of residential buildings in Portuguese climate zones, 
in actual conditions of use. In particular, it aims at giving an answer to the following questions:

- What is the impact of nZEB requirements on building envelope solutions?

- Are the results of regulatory calculation on which nZEB requirements are based comparable to the results of dynamic simulations?

- What is the level of discomfort in a building complying with nZEB requirements when HVAC system is not used?

- How much energy is needed to eliminate discomfort in occupancy hours?

- Can additional passive strategies have a significant effect?

- What is the percentage of energy needs supplied by renewable energy sources in a building complying with minimum nZEB requirements, in actual conditions of use?

\section{Materials and Methods}

\subsection{Standard Dwelling}

For the purpose of the study, a standard dwelling is considered (Figure 1), based on the data available in Construction and Housing Statistics [15].

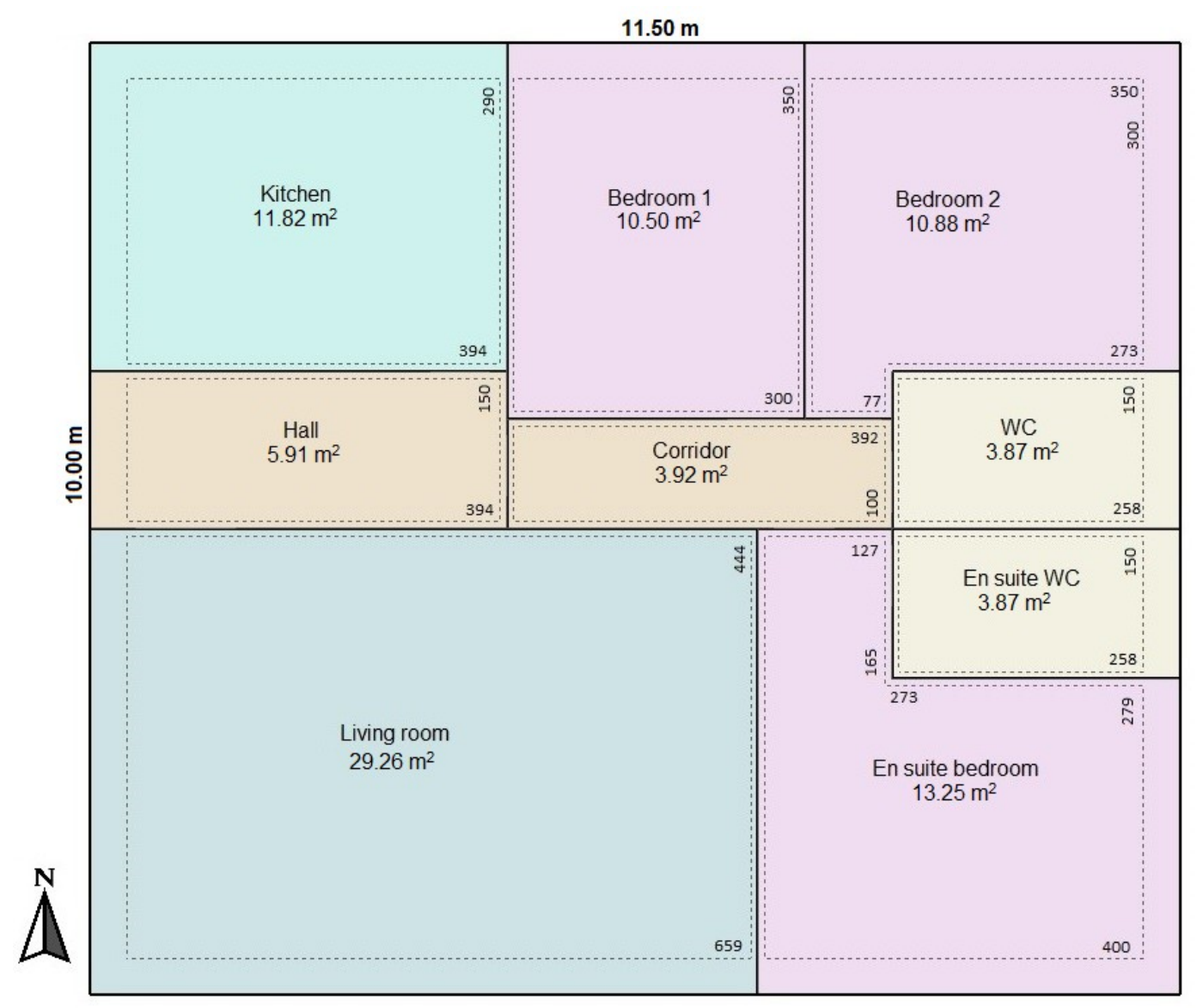

Figure 1. Floor plan of the considered standard dwelling.

Table 1 shows the number of windows in each indoor space, their dimensions, the glazed area and the orientation. All windows have external roller shutters that are closed at night, throughout the year. In the cooling season (months of June, July, August and September), they are also partially closed during the day for solar protection, as follows: on the north façade, no closing is necessary during the day, on the east and south façades the shutters will be closed for $60 \%$ of the day. The air change rate is equal to 0.6 air changes per hour. 
Table 1. Number, area and distribution of windows in the dwelling.

\begin{tabular}{ccccc}
\hline Indoor Space & $\mathbf{N}^{\mathbf{0}}$. of Windows & Dimensions & Glazing Area & Orientation \\
\hline Living Room & 3 & $1.2 \times 1.15 \mathrm{~m}$ & $4.14 \mathrm{~m}^{2}$ & South \\
\hline En suite bedroom & 2 & $1.0 \times 1.15 \mathrm{~m}$ & $2.30 \mathrm{~m}^{2}$ & South \\
\hline En suite WC & 1 & $0.5 \times 0.5 \mathrm{~m}$ & $0.25 \mathrm{~m}^{2}$ & East \\
\hline WC & 1 & $0.5 \times 0.5 \mathrm{~m}$ & $0.25 \mathrm{~m}^{2}$ & East \\
\hline Kitchen & 2 & $1.0 \times 1.15 \mathrm{~m}$ & $2.30 \mathrm{~m}^{2}$ & North \\
\hline Bedroom 1 & 1 & $1.2 \times 1.15 \mathrm{~m}$ & $1.38 \mathrm{~m}^{2}$ & North \\
\hline Bedroom 2 & 1 & $1.2 \times 1.15 \mathrm{~m}$ & $1.38 \mathrm{~m}^{2}$ & North \\
\hline
\end{tabular}

\subsection{Portuguese Climate Zoning}

The Portuguese climate zoning is defined by dividing the territory into three winter climate zones (I1, I2 and I3) and three summer climate zones (V1, V2 and V3) [16]. Winter climate zones are defined in function of the number of heating degree-days (HDD) for a baseline temperature of $18{ }^{\circ} \mathrm{C}$, corresponding to the heating season. Summer climate zones are defined based on the mean outdoor temperature for the conventional cooling season $\left(\theta_{\text {ext,v }}\right)$. The criteria for defining the climate zones and their graphical representation are shown in Table 2 and Figure 2, respectively.

Table 2. Criteria for defining the Portuguese climate zones [16].

\begin{tabular}{cccc}
\hline Winter Criteria & HDD $\leq 1300$ & $1300<\mathrm{HDD} \leq 1800$ & $\mathrm{HDD}>1800$ \\
\hline Winter climate zone & $\mathrm{I} 1$ & $\mathrm{I} 2$ & $\mathrm{I} 3$ \\
\hline Summer criteria & $\theta_{\mathrm{ext}, \mathrm{v}} \leq 20{ }^{\circ} \mathrm{C}$ & $20{ }^{\circ} \mathrm{C}<\theta_{\mathrm{ext}, \mathrm{v}} \leq 22{ }^{\circ} \mathrm{C}$ & $\theta_{\mathrm{ext}, \mathrm{v}}>22{ }^{\circ} \mathrm{C}$ \\
\hline Summer climate zone & $\mathrm{V} 1$ & $\mathrm{~V} 2$ & $\mathrm{~V} 3$ \\
\hline
\end{tabular}

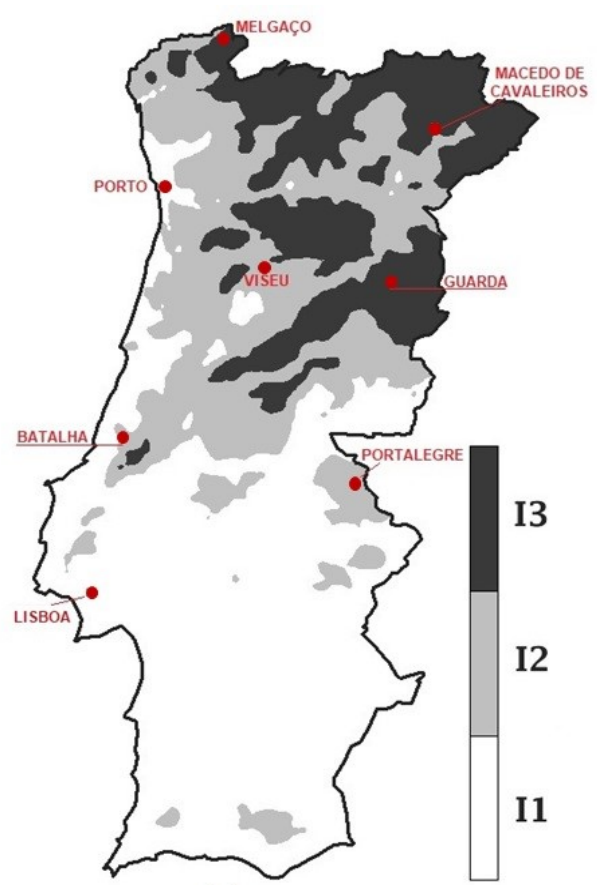

(a)

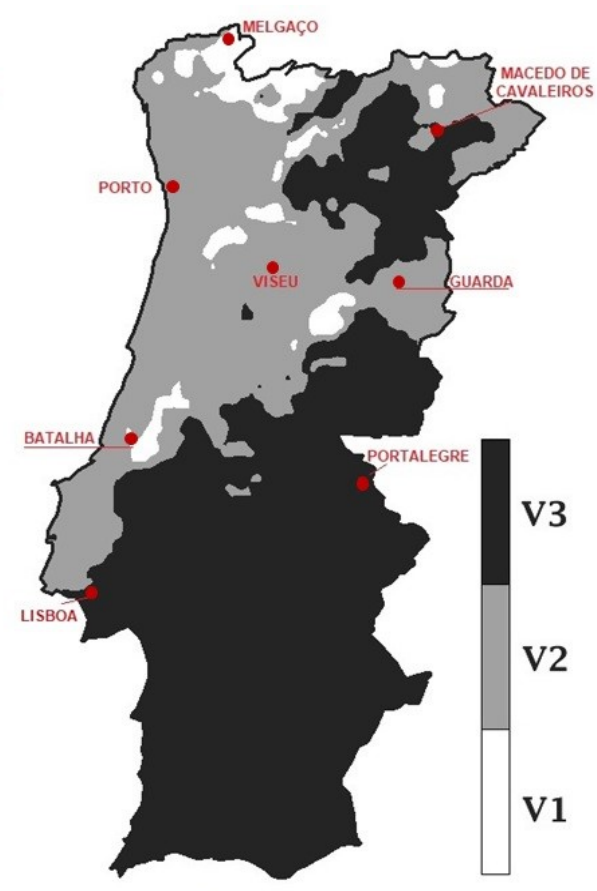

(b)

Figure 2. Graphical representation of the (a) winter climate zones and (b) summer climate zones Adapted from [16]. 
For the calculation of HDD and $\theta_{\text {ext,v }}$, reference values are given for each NUTS III region in [16] and an adjustment must be done for each specific location, in function of their altitude. After overlapping the maps of Figure 2, checking the criteria for the Portuguese municipalities through their altimetry possibilities [17], eight possible combinations were identified for the Portuguese climate zoning. The combination I1V1, which would combine the mildest winter and the mildest summer, does not exist in Portuguese mainland, by the current criteria [16]. The municipalities chosen to represent each of the eight possible combinations of climate zones and the altitude of the chosen location for the building within each municipality are shown in Table 3 . The municipalities are identified on the maps of Figure 2.

Table 3. Combinations of climate zones, representative municipality and location altitude.

\begin{tabular}{ccc}
\hline Climate Zones & Municipality & Altitude \\
\hline I1V2 & Porto & $83 \mathrm{~m}$ \\
\hline I1V3 & Lisboa & $4 \mathrm{~m}$ \\
\hline I2V1 & Batalha & $247 \mathrm{~m}$ \\
\hline I2V2 & Viseu & $475 \mathrm{~m}$ \\
\hline I2V3 & Portalegre & $483 \mathrm{~m}$ \\
\hline I3V1 & Melgaço & $678 \mathrm{~m}$ \\
\hline I3V2 & Guarda & $1017 \mathrm{~m}$ \\
\hline I3V3 & Macedo de Cavaleiros & $572 \mathrm{~m}$ \\
\hline
\end{tabular}

\subsection{Discomfort Assessment}

The concept of degree hours of discomfort is used to assess the discomfort in each of the analyzed situations when the indoor air temperature is outside the defined set points, which means below $18{ }^{\circ} \mathrm{C}$ for heating and above $25^{\circ} \mathrm{C}$ for cooling. For each hourly value of indoor air temperature in that condition, for heating and cooling season, the difference to the respective set point temperature is calculated.

\subsection{Study Phases and Tools}

The study carried out was developed in five phases:

- $\quad$ First phase: first, the quasi-stationary method of Portuguese regulation is used to check if the requirements previously in force, applied to the standard dwelling, could make it reach the nZEB status, in any of the climate zones. Then, using the same method, the construction solutions and the technical systems needed to reach nZEB status with a minimum margin, in each climate zone, are identified.

- $\quad$ Second phase: using those construction solutions and technical systems, the standard dwelling is evaluated, by dynamic simulation, first in free-floating regime for passive comfort assessment and then using the regulatory nominal conditions (heating and cooling systems $\mathrm{ON}, 24 \mathrm{~h}$ a day, with a set point of $18^{\circ} \mathrm{C}$, in the heating season and a set point of $25^{\circ} \mathrm{C}$, in the cooling season) to estimate the energy needs;

- Third phase: a more realistic schedule for the use of HVAC, in winter, is tested for determining, by dynamic simulation, the energy needed and the corresponding thermal comfort conditions. Only natural ventilation is considered for cooling in summer;

- Fourth phase: the energy needed to totally eliminate thermal discomfort in occupancy hours is determined, by dynamic simulation;

- Fifth phase: for the most uncomfortable scenarios and the most adverse climates, the possibilities of improving comfort without increasing energy consumption are analyzed through the implementation of additional passive measures. 
The calculation spreadsheet developed and provided by the Platform for Energy Efficiency in Buildings (P3E) of the Institute for Research and Technological Development in Construction, Energy, Environment and Sustainability (Itecons) [18] is used to verify the compliance with the regulatory requirements, in each of the Portuguese climate zones. The SCE.ER tool [19], made available by the Portuguese General Directorate of Energy and Geology, is used to calculate the contribution of the technical systems of the building that use a renewable energy source locally available (for example, a heat pump) or make the energy from that kind of energy source usable by the household (for example, PV panels). The SCE.ER tool is also a spreadsheet that works as a complement to the first spreadsheet, providing it with an estimation of the mentioned contribution.

DesignBuilder software version 6.1 is used in this study, for all the dynamic simulations. DesignBuilder is an EnergyPlus based software tool used for energy, carbon emissions, lighting and comfort assessment and control. It is widely used to create and evaluate building designs. Validation was performed using the ANSI/ASHRAE Standard 140-2017 (BESTEST) validation test results for DesignBuilder v6.1 with EnergyPlus v8.9, specifically, through the Building Thermal Envelope and Fabric Load Tests [20].

\section{Results}

3.1. First Phase-Characterisation of Minimum nZEB Requirements for Construction Solutions and Technical Systems

Regulatory requirements for new construction $[11,12]$ were in place long before the nZEB requirements were established [13].

Following the method of Portuguese regulation and the spreadsheet that applies it, using thermal parameters calculated according to [21] and complying with the requirements previously in force, it was possible to obtain the values of the annual nominal needs of useful energy for heating $\left(\mathrm{N}_{\mathrm{ic}}\right)$, the annual nominal needs of primary energy $\left(\mathrm{N}_{\mathrm{tc}}\right)$ and the percentage of the annual nominal needs of primary energy that are covered by local renewable energy sources. The annual nominal needs of useful energy for heating $\left(\mathrm{N}_{\mathrm{i}}\right)$ and the annual nominal needs of primary energy $\left(\mathrm{N}_{\mathrm{t}}\right)$ are the maximum allowable values defined by the regulation, based on reference values of the relevant parameters applied to the geometry of the actual building, as explained in the Introduction. The value of the nominal annual useful energy needs for heating the building $\left(\mathrm{N}_{\mathrm{ic}}\right)$ is determined using the real thermal characteristics of the building under analysis and taking into account the heat transfer by transmission through the building envelope, the heat transfer by ventilation and the useful thermal gains resulting from the solar gains and the internal gains (a default value including thermal gains from lighting, equipment and occupants). The value of nominal primary energy needs of the building $\left(\mathrm{N}_{\mathrm{tc}}\right)$ results from the sum of the nominal primary energy needs for heating, cooling, DHW production and mechanical ventilation, deducing any contributions from local renewable energy sources. In order to convert useful energy into primary energy in the calculation of $\mathrm{N}_{\mathrm{tc}}$, useful energy is divided by the efficiency of the respective technical system, converting it into final energy, and then multiplied by a conversion factor depending on the energy source which converts final energy into primary energy. With that calculation, it was checked if the previously existing requirements were sufficient for a residential building to be considered nZEB or at least to comply with any of its conditions. Table 4 shows that the standard dwelling, complying with the requirements previously in force, fails to reach nZEB status at all of the eight analyzed locations. 
Table 4. Results of the regulatory calculation applying the requirements previously in force.

\begin{tabular}{|c|c|c|c|c|c|c|c|c|c|c|c|c|}
\hline \multirow[b]{2}{*}{ Locations } & \multicolumn{4}{|c|}{ Envelope U-Values [W/(m².K)] } & \multirow{2}{*}{$\begin{array}{l}\text { Renewable Energy } \\
\text { Supplied by Solar } \\
\text { Collectors [kWh/year] }\end{array}$} & \multirow{2}{*}{$\begin{array}{c}\mathrm{N}_{\mathrm{ic}} \\
{[\mathrm{kWh} /} \\
\left.\left(\mathrm{m}^{2} \cdot \text { year }\right)\right]\end{array}$} & \multirow{2}{*}{$\begin{array}{c}\mathrm{N}_{\mathrm{i}} \\
{[\mathrm{kWh} /} \\
\left.\left(\mathrm{m}^{2} \cdot \text { year }\right)\right]\end{array}$} & \multirow[b]{2}{*}{$\mathrm{N}_{\mathrm{ic}} / \mathbf{N}_{\mathrm{i}}$} & \multirow{2}{*}{$\begin{array}{c}\mathrm{N}_{\mathrm{tc}} \\
{[\mathrm{kWhEP} /} \\
\left.\left(\mathrm{m}^{2} \text {.year }\right)\right]\end{array}$} & \multirow{2}{*}{$\begin{array}{c}N_{t} \\
{[k W h E P /} \\
\left.\left(\mathrm{m}^{2} . \text { year }\right)\right]\end{array}$} & \multirow[b]{2}{*}{$\mathbf{N}_{\mathrm{tc}} / \mathbf{N}_{\mathrm{t}}$} & \multirow{2}{*}{$\begin{array}{c}\% \text { of Renew } \\
\text { Energy }\end{array}$} \\
\hline & $\begin{array}{l}\text { External } \\
\text { Walls }\end{array}$ & Floor & Roof & Windows & & & & & & & & \\
\hline Porto & 0.50 & 0.46 & 0.38 & 2.80 & 1365 & 50.99 & 65.57 & $77.76 \%$ & 156.51 & 239.72 & $65.29 \%$ & $8.68 \%$ \\
\hline Lisboa & 0.50 & 0.46 & 0.38 & 2.80 & 1503 & 30.71 & 44.42 & $69.14 \%$ & 110.82 & 192.99 & $57.42 \%$ & $12.88 \%$ \\
\hline Batalha & 0.40 & 0.46 & 0.32 & 2.40 & 1476 & 62.25 & 77.87 & $79.94 \%$ & 181.48 & 268.33 & $67.63 \%$ & $8.14 \%$ \\
\hline Viseu & 0.40 & 0.46 & 0.32 & 2.40 & 1411 & 65.99 & 82.86 & $79.64 \%$ & 192.68 & 283.95 & $67.86 \%$ & $7.39 \%$ \\
\hline Portalegre & 0.40 & 0.46 & 0.32 & 2.40 & 1504 & 63.84 & 77.34 & $82.54 \%$ & 205.08 & 286.81 & $71.50 \%$ & $7.40 \%$ \\
\hline Melgaço & 0.34 & 0.46 & 0.27 & 2.20 & 1365 & 99.34 & 113.43 & $87.58 \%$ & 277.4 & 355.3 & $78.07 \%$ & $5.09 \%$ \\
\hline Guarda & 0.34 & 0.46 & 0.27 & 2.20 & 1428 & 97.51 & 112.07 & $87.01 \%$ & 271.01 & 354.47 & $76.45 \%$ & $5.43 \%$ \\
\hline $\begin{array}{l}\text { Macedo de } \\
\text { Cavaleiros }\end{array}$ & 0.34 & 0.46 & 0.27 & 2.20 & 1335 & 76.85 & 91.32 & $84.15 \%$ & 228.11 & 307.89 & $74.09 \%$ & $6.00 \%$ \\
\hline
\end{tabular}


None of the three conditions necessary to be considered an nZEB (which are $\mathrm{N}_{\mathrm{ic}} / \mathrm{N}_{\mathrm{i}} \leq$ $75 \%, N_{t c} / N_{t} \leq 50 \%$ and a percentage of renewable energy contribution $\geq 50 \%$ of primary energy needs) was met at seven of the eight locations.

In Lisboa, the dwelling meets the first condition $\mathrm{N}_{\mathrm{ic}} / \mathrm{N}_{\mathrm{i}} \leq 75 \%$. In the other seven climate zones, changes were necessary. In Table 5, the U-values of the building envelope that needed to be changed in order to achieve, as closely as possible, the requirement for $\mathrm{N}_{\mathrm{ic}} / \mathrm{N}_{\mathrm{i}} \leq 75 \%$ are highlighted in bold. Therefore, these new U-values represent, for the standard dwelling, the maximum values that still allow reaching nZEB status. Other changes were needed too, namely, the definition of efficient technical systems and the increase of local renewable energy contribution in order to meet the second condition, $\mathrm{N}_{\mathrm{tc}} / \mathrm{N}_{\mathrm{t}} \leq 50 \%$. The same split air conditioning system was installed for space heating and cooling, in all cases. In what concerns heat pumps for water heating and photovoltaic panels, the models and their number and size, for each climate zone, were chosen so that the condition $\mathrm{N}_{\mathrm{tc}} / \mathrm{N}_{\mathrm{t}} \leq 50 \%$ could be met with the lowest margin possible, thus showing the impact of nZEB status on the minimum requirements for these systems.

Table 5 shows that the third condition for a building to be considered nZEB, local renewable energy covering at least $50 \%$ of primary energy needs, was achieved with a significant margin. Following a logical order of compliance with the first condition and after that, with the second condition, which were both met with a minimum margin, a significant margin occurred in the third criterion because the authors opted for high-efficiency models of technical systems that works, in a low percentage, on electricity supplied by the grid and, in a high percentage, on energy from a local renewable source, the air, reducing $\mathrm{N}_{\mathrm{tc}}$ just what was needed to comply with $\mathrm{N}_{\mathrm{tc}} / \mathrm{N}_{\mathrm{t}} \leq 50 \%$ but introducing a significant contribution of renewables. This choice results in a minimum need of photovoltaic panels for the supply of renewable energy. Other options of systems could lead to a high need of PV panels, which is often not easy to manage.

Table 6 shows all the construction solutions of the building envelope used in the analyzed cases, as well as the technical systems.

\subsection{Second Phase-Dynamic Simulation of the Standard Dwelling Complying with $n Z E B$ Requirements}

After obtaining all the necessary parameters for minimum compliance with the nZEB requirements, the performance of the standard dwelling was simulated, first in free-floating regime, with no heating nor cooling, in order to assess passive comfort and after that, in the regulatory nominal conditions which means that the HVAC system is permanently in operation, $24 \mathrm{~h}$ a day, during the whole heating season and during the whole cooling season, with setpoint temperatures of $18{ }^{\circ} \mathrm{C}$ for heating and $25{ }^{\circ} \mathrm{C}$ for cooling. The second simulation gives an estimation of the energy needed to keep indoor environment comfortable. 
Table 5. Results of the compliance with nZEB requirements $\left(\mathrm{N}_{\mathrm{ic}}, \mathrm{N}_{\mathrm{i}}, \mathrm{N}_{\mathrm{tc}}\right.$ and $\mathrm{N}_{\mathrm{t}}$, in $\mathrm{kWh} /\left(\mathrm{m}^{2}\right.$.year $)$ ).

\begin{tabular}{|c|c|c|c|c|c|c|c|c|c|c|c|c|c|}
\hline \multirow{3}{*}{ Locations } & \multicolumn{4}{|c|}{ 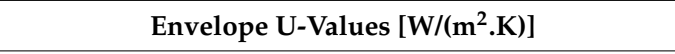 } & \multirow{2}{*}{\multicolumn{2}{|c|}{$\begin{array}{c}\text { Renewable Energy } \\
\text { Supplied by Solar Collectors } \\
{[\mathrm{kWh} / \text { year }]}\end{array}$}} & \multirow{3}{*}{$\mathbf{N}_{\mathrm{ic}}$} & \multirow{3}{*}{$\mathbf{N}_{\mathrm{i}}$} & \multirow{3}{*}{$\begin{array}{l}\mathrm{N}_{\mathrm{ic}} / \mathrm{N}_{\mathrm{i}} \\
(<75 \%)\end{array}$} & \multirow{3}{*}{$\mathbf{N}_{\mathrm{tc}}$} & \multirow{3}{*}{$\mathbf{N}_{\mathrm{t}}$} & \multirow{3}{*}{$\begin{array}{l}\mathrm{N}_{\mathrm{tc}} / \mathrm{N}_{\mathrm{t}} \\
(<50 \%)\end{array}$} & \multirow{2}{*}{$\begin{array}{c}\% \text { of Renew. Energ } . \\
(>50 \%)\end{array}$} \\
\hline & External Walls & Floor & Roof & Windows & & & & & & & & & \\
\hline & & & & & PV $240 \mathrm{~W}$ & 374 & & & & & & & \\
\hline \multirow{2}{*}{ Porto } & & & & & AC Split & 3299.49 & & & & & & & \\
\hline & & & & & PV $240 \mathrm{~W}$ & 403 & & & & & & & \\
\hline \multirow[t]{2}{*}{ Lisboa } & 0.50 & 0.46 & 0.38 & 2.80 & Heat Pump BC150 & 1748.37 & 30.71 & 44.42 & $69.14 \%$ & 33.84 & 69.55 & $48.66 \%$ & $64.10 \%$ \\
\hline & & & & & PV $260 \mathrm{~W}$ & 426 & & & & & & & \\
\hline \multirow[t]{3}{*}{ Batalha } & 0.34 & 0.46 & 0.27 & 2.40 & Heat Pump BC200 & 1781.47 & 58.34 & 77.87 & $74.92 \%$ & 42.9 & 85.86 & $49.97 \%$ & $63.32 \%$ \\
\hline & & & & & AC Split & 3947 & & & & & & & \\
\hline & & & & & PV $245 \mathrm{~W}$ & 388 & & & & & & & \\
\hline \multirow[t]{3}{*}{ Viseu } & 0.34 & 0.46 & 0.27 & 2.40 & Heat Pump BC200 & 1781.47 & 61.81 & 82.86 & $74.60 \%$ & 46.22 & 92.67 & $49.88 \%$ & $62.05 \%$ \\
\hline & & & & & AC Split & 4181.88 & & & & & & & \\
\hline & & & & & $2 \times \mathrm{PV} 240 \mathrm{~W}$ & 799 & & & & & & & \\
\hline \multirow{2}{*}{ Portalegre } & & & & & AC Split & 5465.07 & & & & & & & \\
\hline & & & & & $2 \times \mathrm{PV} 240 \mathrm{~W}$ & 737 & & & & & & & \\
\hline \multirow[t]{3}{*}{ Melgaço } & 0.24 & 0.29 & 0.27 & 2.00 & Heat Pump ACS200 & 1665.52 & 84.04 & 113.43 & $74.09 \%$ & 54.46 & 110.08 & $49.47 \%$ & $64.79 \%$ \\
\hline & & & & & AC Split & 5686.1 & & & & & & & \\
\hline & & & & & $2 \times \mathrm{PV} 240 \mathrm{~W}$ & 770 & & & & & & & \\
\hline \multirow[t]{2}{*}{ Guarda } & 0.24 & 0.29 & 0.27 & 2.20 & Heat Pump ACS230 & 1590.1 & 83.73 & 112.07 & $74.71 \%$ & 55.41 & 111.64 & $49.63 \%$ & $64.36 \%$ \\
\hline & & & & & AC Split & 5665.04 & & & & & & & \\
\hline \multirow{3}{*}{$\begin{array}{l}\text { Macedo de } \\
\text { Cavaleiros }\end{array}$} & & & & & $2 \times \mathrm{PV} 240 \mathrm{~W}$ & 727 & & & & & & & \\
\hline & 0.24 & 0.36 & 0.27 & 2.20 & Heat Pump ACS200 & 1665.52 & 67.94 & 91.32 & $74.40 \%$ & 49.58 & 101.68 & $48.76 \%$ & $65.47 \%$ \\
\hline & & & & & AC Split & 5108.02 & & & & & & & \\
\hline
\end{tabular}


Table 6. Envelope construction solutions and technical systems.

\begin{tabular}{|c|c|c|}
\hline Envelope & $\begin{array}{c}\text { U-Value } \\
{\left[\mathrm{W} /\left(\mathrm{m}^{2}{ }^{\circ} \mathrm{C}\right)\right]}\end{array}$ & Solution Description \\
\hline External walls & $\begin{array}{l}0.40 \\
0.34 \\
0.31 \\
0.24\end{array}$ & $\begin{array}{l}\text { Double wall with } 15 \mathrm{~cm}+11 \mathrm{~cm} \text { hollow brick masonry, rendered in both faces with } 2 \\
\text { cm cement mortar } \\
\text { with } 8 \mathrm{~cm} \text { non-ventilated air gap }+4 \mathrm{~cm} \text { EPS, between walls } \\
\text { The same double wall with } 6 \mathrm{~cm} \text { non-ventilated air gap }+6 \mathrm{~cm} \text { EPS, between walls } \\
\text { The same double wall with } 4 \mathrm{~cm} \text { non-ventilated air gap }+8 \mathrm{~cm} \text { EPS, between walls } \\
\text { The same double wall with } 4 \mathrm{~cm} \text { non-ventilated air gap }+8 \mathrm{~cm} \text { XPS, between walls } \\
\text { The same double wall with } 12 \mathrm{~cm} \text { XPS, between walls }\end{array}$ \\
\hline Floor & $\begin{array}{l}0.46 \\
0.36 \\
0.29\end{array}$ & $\begin{array}{c}20 \mathrm{~cm} \text { gravel }+5 \mathrm{~cm} \text { screed }+2 \mathrm{~cm} \text { EPS }+10 \mathrm{~cm} \text { reinforced rigging }+5 \mathrm{~cm} \text { light } \\
\text { concrete }+2 \mathrm{~cm} \text { leveling screed }+1 \mathrm{~cm} \text { ceramic coating } \\
\text { The same floor solution, with } 4 \mathrm{~cm} \text { XPS } \\
\text { The same floor solution, with } 6 \mathrm{~cm} \text { XPS }\end{array}$ \\
\hline Roof & $\begin{array}{l}0.38 \\
0.32 \\
0.27\end{array}$ & $\begin{array}{l}\text { Pitched roof with ceramic tiles and slab: } 2 \mathrm{~cm} \text { mortar cement coating }+25 \mathrm{~cm} \text { hollow } \\
\text { blocks and concrete ribs slab }+8 \mathrm{~cm} \text { XPS } \\
\text { The same roof with } 10 \mathrm{~cm} \text { XPS } \\
\text { The same roof with } 12 \mathrm{~cm} \text { XPS }\end{array}$ \\
\hline Windows [22] & $\begin{array}{l}2.80 \\
2.40 \\
2.20 \\
2.00\end{array}$ & $\begin{array}{l}\text { Window with a double glass, } 6 \mathrm{~mm} \text { spacing between glasses, with an external roller } \\
\text { shutter and a shutter box with high air permeability } \\
\text { The same window with } 16 \mathrm{~mm} \text { spacing between glasses } \\
\text { The same window with } 16 \mathrm{~mm} \text { spacing between glasses, but with a shutter box with } \\
\text { low air permeability } \\
\text { Window with double glass with low emissivity, } 16 \mathrm{~mm} \text { spacing between glasses and } \\
\text { a shutter box with low air permeability }\end{array}$ \\
\hline Technical systems & Model & Solution description \\
\hline PV panels [23] & $\begin{array}{l}240 \mathrm{PE} \\
245 \mathrm{PE} \\
260 \mathrm{PE}\end{array}$ & $\begin{array}{l}\text { Photovoltaic panels-peak energy BLK series, } 240 \mathrm{~W} \\
\text { Photovoltaic panels-peak energy BLK series, } 245 \mathrm{~W} \\
\text { Photovoltaic panels REC peak energy BLK series, } 260 \mathrm{~W}\end{array}$ \\
\hline Heat pump [24-26] & $\begin{array}{l}\text { Split150 } \\
\text { Split200 } \\
\text { IN200 } \\
\text { IN230 }\end{array}$ & $\begin{array}{l}\text { DHW Heat pump Split model 150, with COP: } 3.78 \\
\text { DHW Heat pump Split model 200, with COP: } 3.99 \\
\text { DHW Heat pump IN model 200, with COP: } 3.34 \\
\text { DHW Heat pump IN model 230, with COP: } 3.02\end{array}$ \\
\hline AC Split & & $\begin{array}{l}\text { Residential Split Air Conditioning } 2.5 \text { kW R32, with EER (Cooling): 3.57; COP } \\
\text { (Heating): } 3.81 \text { [27] }\end{array}$ \\
\hline
\end{tabular}

Figure 3 shows the degree-hours of discomfort for each location, when the dwelling is in free-floating regime. Figure 3a, gives the daily sum of degree-hours, over the year, with the negative values representing the cold-induced discomfort and the positive values representing the heat-induced discomfort. Figure $3 \mathrm{~b}$ shows the annual sum of the degreehours of discomfort for cold (heating season) and for heat (cooling season), as well as the total values.

Table 7 shows the values of the useful energy needs calculated through the quasistationary method of the regulation and through dynamic simulation and values of PV production calculated through the SCE.ER spreadsheet and through dynamic simulation. It should be noted that the quasi-stationary method of Portuguese regulation tends to overestimate heating needs for all the regions, except the two coldest ones. In contrast, the cooling needs are highly underestimated. The variations found in the values of PV energy production are minor. 


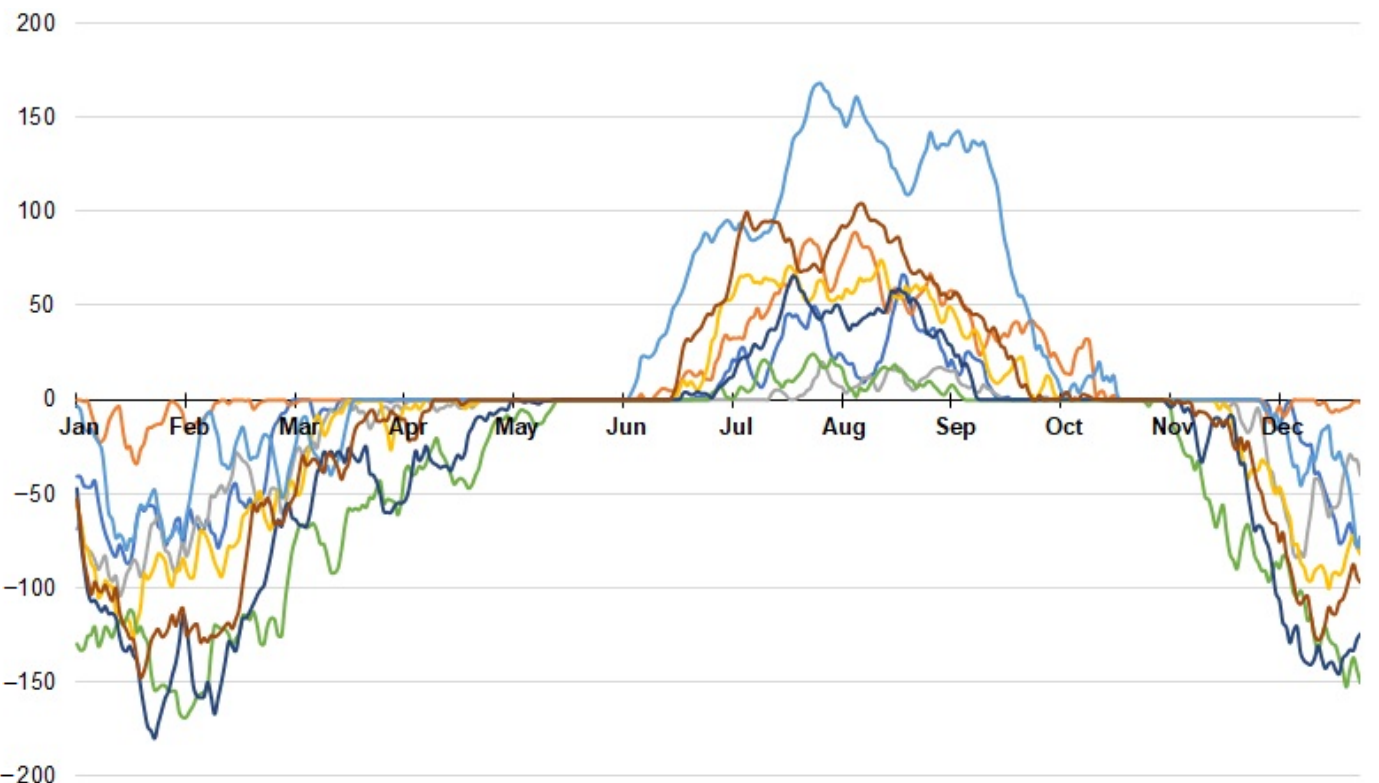

$-200$

(a)

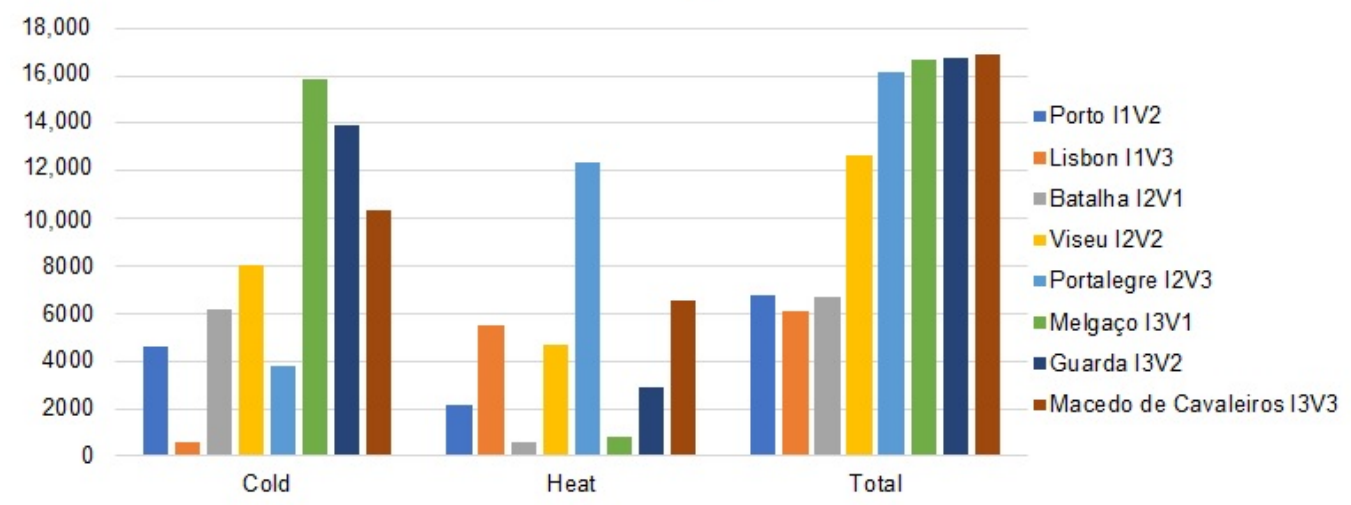

(b)

Figure 3. Degree-hours of discomfort without heating or cooling: (a) daily sum, over the year, with negative values indicating discomfort due to cold and positive values indicating discomfort due to heat; (b) seasonal and annual sum of degree-hours of discomfort (absolute values).

Table 7. Values of the useful energy needs calculated through the quasi-stationary method of the regulation and through dynamic simulation and values of PV production calculated through the SCE.ER spreadsheet and through dynamic simulation.

\begin{tabular}{|c|c|c|c|c|c|c|c|c|c|}
\hline \multirow[t]{2}{*}{ Locations } & \multicolumn{2}{|c|}{$\begin{array}{l}\text { Useful Energy Needs } \\
\text { through the Regulation } \\
\text { Method [kWh/(m².year)] }\end{array}$} & \multicolumn{4}{|c|}{$\begin{array}{l}\text { Useful Energy Needs through Dynamic Simulation } \\
\qquad\left[\mathrm{kWh} /\left(\mathrm{m}^{2} \text {.year }\right)\right]\end{array}$} & \multicolumn{3}{|c|}{ PV Production [kWh/year] } \\
\hline & $\mathbf{N}_{\mathrm{ic}}$ & $\mathbf{N}_{\mathrm{vc}}$ & For Heating & $\begin{array}{l}\text { Variation in } \\
\text { Relation to } \mathrm{N}_{\mathrm{ic}}\end{array}$ & For Cooling & $\begin{array}{l}\text { Variation in } \\
\text { Relation to } \mathrm{N}_{\mathrm{vc}}\end{array}$ & $\begin{array}{l}\text { (a) } \\
\text { SCE.ER }\end{array}$ & $\begin{array}{c}\text { (b) } \\
\text { Simulation }\end{array}$ & $\begin{array}{l}\text { Variation from } \\
\text { (a) to (b) }\end{array}$ \\
\hline Porto & 48.77 & 3.38 & 38.68 & $-21 \%$ & 15.22 & $+350 \%$ & 374 & 334.3 & $-11 \%$ \\
\hline Lisboa & 30.71 & 10.75 & 10.13 & $-67 \%$ & 59.48 & $+453 \%$ & 403 & 368.2 & $-9 \%$ \\
\hline Batalha & 58.34 & 1.64 & 45.20 & $-23 \%$ & 9.95 & $+507 \%$ & 426 & 393.0 & $-8 \%$ \\
\hline Viseu & 61.81 & 3.82 & 56.52 & $-9 \%$ & 29.23 & $+665 \%$ & 388 & 393.8 & $1 \%$ \\
\hline Portalegre & 57.9 & 23.44 & 30.75 & $-47 \%$ & 72.75 & $+210 \%$ & 799 & 732.3 & $-8 \%$ \\
\hline Melgaço & 84.04 & 1.29 & 92.61 & $+10 \%$ & 7.36 & $+471 \%$ & 737 & 654.1 & $-11 \%$ \\
\hline Guarda & 83.73 & 2.67 & 85.49 & $+2 \%$ & 19.92 & $+646 \%$ & 770 & 696.4 & $-10 \%$ \\
\hline $\begin{array}{l}\text { Macedo de } \\
\text { Cavaleiros }\end{array}$ & 67.94 & 8.23 & 67.00 & $-1 \%$ & 18.19 & $+121 \%$ & 727 & 649.5 & $-11 \%$ \\
\hline
\end{tabular}




\subsection{Third Phase-Realistic Schedule for the Use of HVAC}

The continuous use of HVAC systems is not common in Portuguese dwellings. Furthermore, an nZEB is expected to provide a certain degree of passive comfort to users, especially in mild climates. Thus, for the third phase of this study, it was established that the HVAC system would only be used for heating and would be activated between 18:00 and 23:00, during the heating season. For cooling, natural ventilation is used during the cooling season (June to September), whenever the indoor temperature is higher than the outdoor temperature and if the outdoor temperature is at least $18{ }^{\circ} \mathrm{C}$, with a limit of four air changes per hour.

Figure 4 shows the degree-hours of discomfort for each location with the usage profile described. Figure 4a presents the daily sum of degree-hours, with the negative values representing the cold-induced discomfort and the positive values the heat-induced discomfort. Figure $4 \mathrm{~b}$ presents the annual sum of the degree-hours of discomfort due to cold (heating season), due to heat (cooling season), as well as the total values. Figure 4 uses the same graph scales as Figure 3, for a better comparison between the two situations.

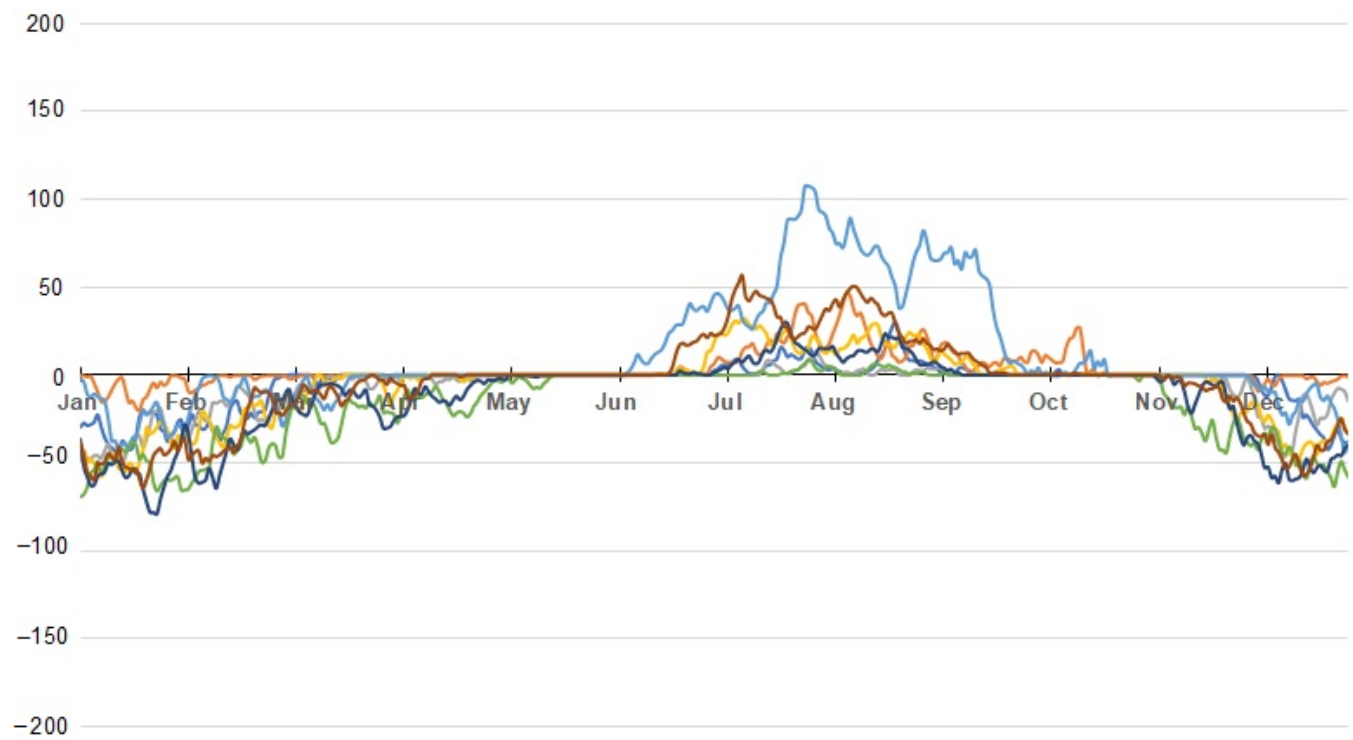

(a)

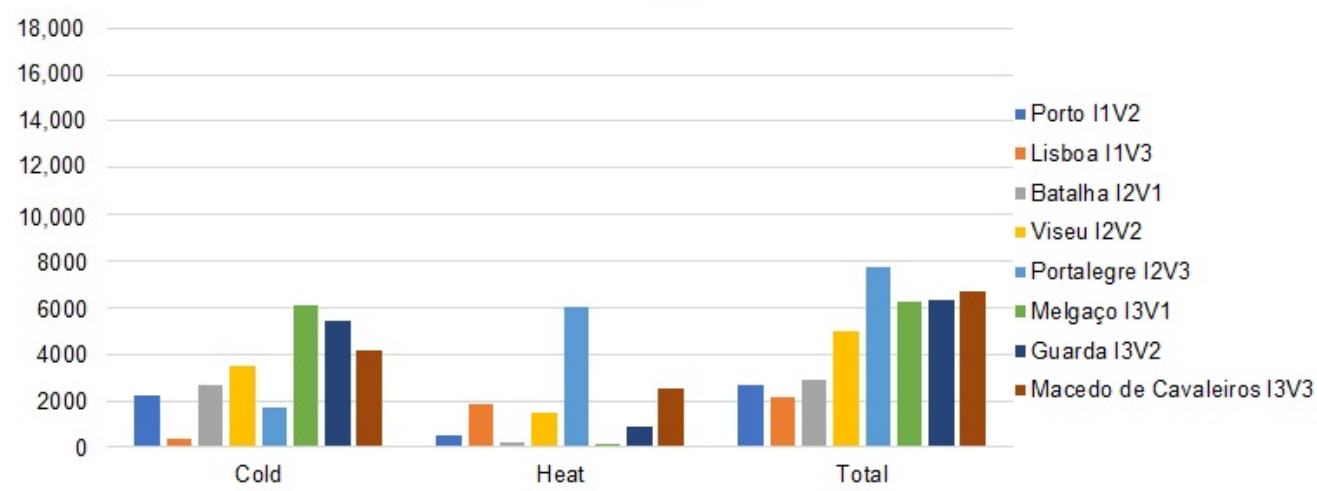

(b)

Figure 4. Degree-hours of discomfort for the defined more realistic usage profile: (a) daily sum, over the year, with negative values indicating discomfort due to cold and positive values indicating discomfort due to heat; (b) seasonal and annual sum of degree-hours of discomfort (absolute values).

Figures 3 and 4 show the degree-hours of discomfort, throughout the $24 \mathrm{~h}$ of the day. Figure 5 shows the degree-hours of discomfort, for the realistic usage profile but 
only during the occupancy hours, which were considered to be between 18:00 and 07:00. Figure 5 does not use the same graph scales as the previous figures, in order to visualize the data better since the numbers are considerably lower.

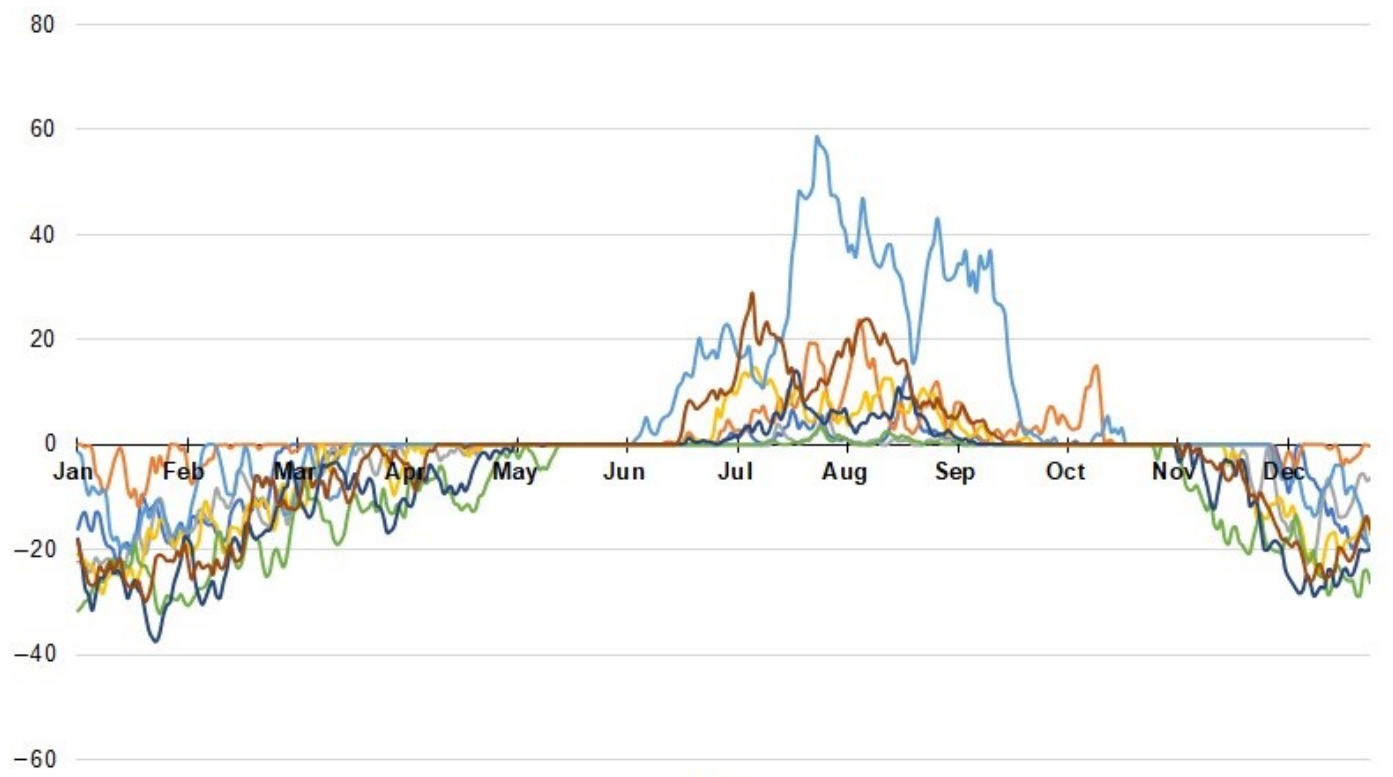

(a)

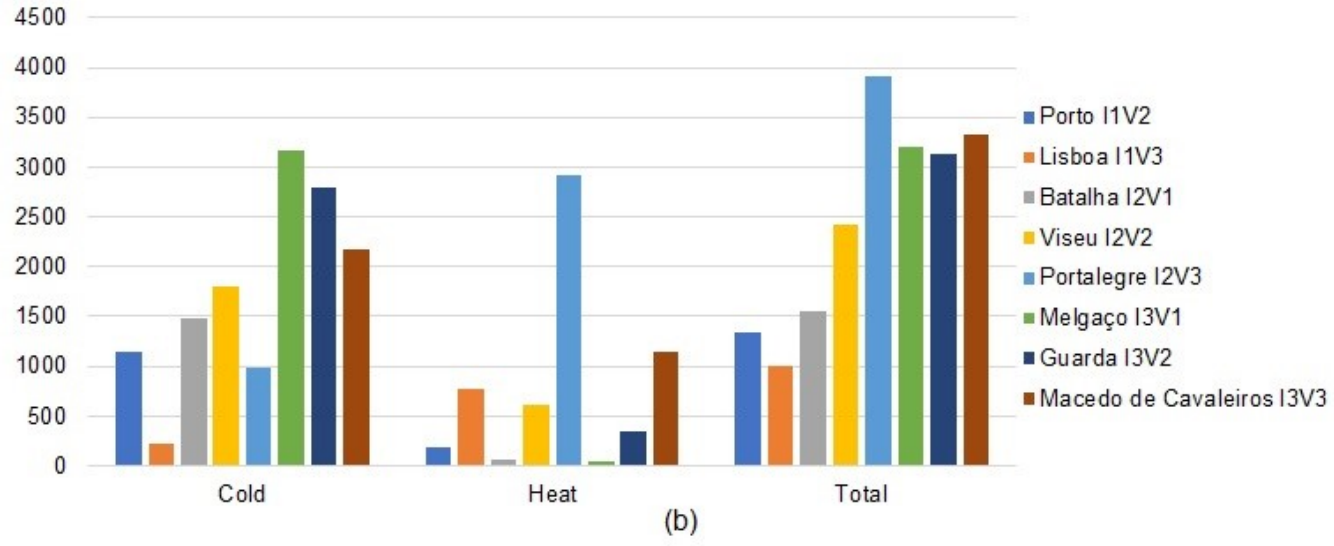

Figure 5. Degree-hours of discomfort for the defined more realistic usage profile, when the dwelling is occupied: (a) daily sum, over the year, with negative values indicating discomfort due to cold and positive values indicating discomfort due to heat; (b) seasonal and annual sum of degree-hours of discomfort (absolute values).

As expected, the realistic usage profile leads to a considerable reduction in heating and cooling energy consumption compared to the regulatory nominal conditions of continuous HVAC use. Table 8 shows that reduction for each location.

However, there are still periods of discomfort during the occupancy hours, which vary in intensity depending on the climate. Therefore, it is necessary to investigate the energy consumption needed to provide comfort through the HVAC system, during the whole period of occupancy, in addition to the possibility of using natural ventilation for cooling. 
Table 8. Energy consumption, in kWh/year, in regulatory nominal conditions, with a realistic HVAC schedule and for ensuring occupancy thermal comfort.

\begin{tabular}{|c|c|c|c|c|c|c|}
\hline Location & End Use & $\begin{array}{c}\text { Regulatory } \\
\text { Nominal } \\
\text { Conditions (A) }\end{array}$ & $\begin{array}{l}\text { Realistic } \\
\text { HVAC } \\
\text { Schedule }\end{array}$ & $\begin{array}{c}\text { Variation in } \\
\text { Relation to (A) }\end{array}$ & $\begin{array}{l}\text { Occupancy } \\
\text { Comfort }\end{array}$ & $\begin{array}{c}\text { Variation in } \\
\text { Relation to (A) }\end{array}$ \\
\hline \multirow{3}{*}{$\begin{array}{l}\text { Porto } \\
\text { I1V2 }\end{array}$} & Heating & 931.40 & 431.85 & $-53.6 \%$ & 756.34 & $-18.8 \%$ \\
\hline & Cooling & 391.26 & 0.00 & $-100.0 \%$ & 60.58 & $-84.5 \%$ \\
\hline & Heating + Cooling & 1322.66 & 431.85 & $-67.3 \%$ & 816.92 & $-38.2 \%$ \\
\hline \multirow{3}{*}{$\begin{array}{l}\text { Lisboa } \\
\text { I1V3 }\end{array}$} & Heating & 243.90 & 84.76 & $-65.2 \%$ & 191.82 & $-21.4 \%$ \\
\hline & Cooling & 1528.67 & 0.00 & $-100.0 \%$ & 552.45 & $-63.9 \%$ \\
\hline & Heating + Cooling & 1772.57 & 84.76 & $-95.2 \%$ & 744.27 & $-58.0 \%$ \\
\hline \multirow{3}{*}{$\begin{array}{l}\text { Batalha } \\
\text { I2V1 }\end{array}$} & Heating & 1088.45 & 518.59 & $-52.4 \%$ & 908.24 & $-16.6 \%$ \\
\hline & Cooling & 255.66 & 0.00 & $-100.0 \%$ & 78.26 & $-69.4 \%$ \\
\hline & Heating+Cooling & 1344.11 & 518.59 & $-61.4 \%$ & 986.50 & $-26.6 \%$ \\
\hline \multirow{3}{*}{$\begin{array}{l}\text { Viseu } \\
\text { I2V2 }\end{array}$} & Heating & 1361.12 & 681.18 & $-50.0 \%$ & 1129.52 & $-17.0 \%$ \\
\hline & Cooling & 751.34 & 0.00 & $-100.0 \%$ & 182.99 & $-75.6 \%$ \\
\hline & Heating + Cooling & 2112.46 & 681.18 & $-67.8 \%$ & 1312.51 & $-37.9 \%$ \\
\hline \multirow{3}{*}{$\begin{array}{l}\text { Portalegre } \\
\text { I2V3 }\end{array}$} & Heating & 740.45 & 342.28 & $-53.8 \%$ & 621.50 & $-16.1 \%$ \\
\hline & Cooling & 1869.80 & 0.00 & $-100.0 \%$ & 984.30 & $-47.4 \%$ \\
\hline & Heating + Cooling & 2610.25 & 342.28 & $-86.9 \%$ & 1605.80 & $-38.5 \%$ \\
\hline \multirow{3}{*}{ Melgaço I3V1 } & Heating & 2230.23 & 1227.58 & $-45.0 \%$ & 1915.28 & $-14.1 \%$ \\
\hline & Cooling & 189.24 & 0.00 & $-100.0 \%$ & 30.93 & $-83.7 \%$ \\
\hline & Heating+Cooling & 2419.47 & 1227.58 & $-49.3 \%$ & 1946.21 & $-19.6 \%$ \\
\hline \multirow{3}{*}{$\begin{array}{l}\text { Guarda } \\
\text { I3V2 }\end{array}$} & Heating & 2058.74 & 1136.23 & $-44.8 \%$ & 1755.28 & $-14.7 \%$ \\
\hline & Cooling & 511.95 & 0.00 & $-100.0 \%$ & 176.68 & $-65.5 \%$ \\
\hline & Heating+Cooling & 2570.69 & 1136.23 & $-55.8 \%$ & 1931.96 & $-24.8 \%$ \\
\hline Macedo de & Heating & 1613.48 & 845.26 & $-47.6 \%$ & 1345.73 & $-16.6 \%$ \\
\hline Cavaleiros & Cooling & 467.55 & 0.00 & $-100.0 \%$ & 121.62 & $-74.0 \%$ \\
\hline I3V3 & Heating+Cooling & 2081.03 & 845.26 & $-59.4 \%$ & 1467.35 & $-29.5 \%$ \\
\hline
\end{tabular}

\subsection{Fourth Phase-Energy Consumption Needed to Ensure Thermal Comfort during Occupancy}

The results presented in the previous point, through Figure 5, shows that the degreehours of discomfort during periods of occupancy, assuming a more realistic usage profile, are quite low, offering a very significant reduction in energy consumption. However, there is still some discomfort. Thus, another simulation was carried out to estimate the energy consumption needed to eliminate discomfort during occupancy. Natural ventilation is also used in periods where it is possible to guarantee comfort through this passive strategy.

Table 8 shows the energy consumption using the HVAC system, during the occupancy, in such a way that ensures thermal comfort to the users. In these conditions, since the HVAC system is only used in the occupancy periods, the values of energy consumption are obviously lower than the ones of the regulatory nominal conditions that correspond to a continuous use of it.

\subsection{Fifth Phase-Additional Passive Strategies for the Most Critical Locations}

By analyzing the results for all the locations, presented in Figures $3-5$, it is possible to notice that Melgaço and Guarda present significant cold-induced discomfort. In contrast, Portalegre presents high heat-induced discomfort. In order to reduce discomfort in these three locations, some additional passive strategies were tested.

For Melgaço and Guarda, which have more significant discomfort due to cold, the strategy used was to increase the glazing area on the south façade to enhance solar passive gains during the heating season. Two attempts were made for each location: in the first attempt, the three windows in the living room and the two windows in the en suite bedroom were enlarged to a width of $1.5 \mathrm{~m}$; in the second attempt, the width of these same windows was increased to $1.6 \mathrm{~m}$. The height was kept at its original value of $1.15 \mathrm{~m}$.

Table 9 shows the results of the attempts to reduce cold discomfort in the cases of Melgaço and Guarda. As expected, in addition to reducing cold-induced discomfort in 
winter, there is a slight increase in discomfort due to heat in summer. However, the total degree-hours of discomfort presents a reduction of about $20 \%$ in both locations, for the larger glazing dimensions. The values of discomfort due to cold are much higher than the ones of discomfort due to heat, so the tested strategy results in a significant general comfort gain. In addition to improving occupant comfort conditions, it was also possible to reduce around $24 \%$ in energy consumption for heating, which further confirms this strategy benefits in these two cold winter climate zones.

Table 9. Results of attempts to reduce the degree-hours of discomfort at the most critical locations.

\begin{tabular}{|c|c|c|c|c|c|c|c|}
\hline & & & $\begin{array}{l}\text { Realistic HVAC } \\
\text { Schedule }\end{array}$ & First & empt & Secon & tempt \\
\hline \multirow{4}{*}{$\begin{array}{l}\text { Melgaço } \\
\text { I3V1 }\end{array}$} & \multirow{3}{*}{$\begin{array}{l}\text { Degree-hours of } \\
\text { discomfort during } \\
\text { occupancy }\end{array}$} & Due to cold & 3162.85 & 2604.38 & $-17.7 \%$ & 2491.83 & $-21.2 \%$ \\
\hline & & Due to heat & 46.14 & 63.40 & $37.4 \%$ & 67.31 & $45.9 \%$ \\
\hline & & Total & 3208.99 & 2667.78 & $-16.9 \%$ & 2559.14 & $-20.3 \%$ \\
\hline & \multicolumn{2}{|c|}{$\begin{array}{l}\text { Heating energy consumption } \\
{[\mathrm{kWh} / \text { year }]}\end{array}$} & 1227.58 & 982.64 & $-20.0 \%$ & 937.54 & $-23.6 \%$ \\
\hline \multirow{4}{*}{$\begin{array}{l}\text { Guarda } \\
\text { I3V2 }\end{array}$} & \multirow{3}{*}{$\begin{array}{l}\text { Degree-hours of } \\
\text { discomfort during } \\
\text { occupancy }\end{array}$} & Due to cold & 2793.62 & 2208.94 & $-20.9 \%$ & 2086.36 & $-25.3 \%$ \\
\hline & & Due to heat & 339.81 & 399.67 & $17.6 \%$ & 416.26 & $22.5 \%$ \\
\hline & & Total & 3133.43 & 2608.60 & $-16.7 \%$ & 2502.62 & $-20.1 \%$ \\
\hline & \multicolumn{2}{|c|}{$\begin{array}{l}\text { Heating energy consumption } \\
{[\mathrm{kWh} / \text { year }]}\end{array}$} & 1136.23 & 908.01 & $-20.1 \%$ & 858.11 & $-24.5 \%$ \\
\hline \multirow{4}{*}{$\begin{array}{l}\text { Portalegre } \\
\text { I2V3 }\end{array}$} & \multirow{3}{*}{$\begin{array}{l}\text { Degree-hours of } \\
\text { discomfort during } \\
\text { occupancy }\end{array}$} & Due to cold & 983.17 & 983.24 & $0.0 \%$ & 989.372 & $0.6 \%$ \\
\hline & & Due to heat & 2922.77 & 2295.76 & $-21.5 \%$ & 2258.32 & $-22.7 \%$ \\
\hline & & Total & 3905.94 & 3279 & $-16.1 \%$ & 3247.69 & $-16.9 \%$ \\
\hline & \multicolumn{2}{|c|}{$\begin{array}{l}\text { Heating energy consumption } \\
{[\mathrm{kWh} / \text { year }]}\end{array}$} & 342.28 & 342.31 & $0.0 \%$ & 344.25 & $0.6 \%$ \\
\hline
\end{tabular}

For the case of Portalegre, the strategy used to reduce degree-hours of discomfort due to heat was to increase the rate of natural ventilation. In the first attempt, the air change rate goes from 4 ach to 6 ach, with the same criteria defined in the third phase of the study. In the second attempt, in addition to this modification, the period for the use of natural ventilation and the shading of glazing during the day in summer months is also changed to reduce heat gains: they are used from May to October, instead of from June to September, as before.

Table 9 shows the results of the attempts to reduce discomfort due to heat in the case of Portalegre. In both attempts, there is a significant reduction of degree-hours of discomfort due to heat, a total reduction of more than $16 \%$. Since the aforementioned strategies are applied only in summer, there is no negative effect in winter, i.e., no increase of degree-hours of discomfort due to cold nor of heating energy consumption.

In addition to reducing the degree-hours of discomfort in the three most critical locations, it is also possible to obtain a reduction in energy consumption for the HVAC system, as shown in Table 10. 
Table 10. HVAC energy consumption, in kWh/year; in the scenarios with additional passive strategies, compared to energy consumption in regulatory nominal conditions and to energy consumption for ensuring occupancy thermal comfort before the passive strategies.

\begin{tabular}{|c|c|c|c|c|c|c|}
\hline Location & End Use & $\begin{array}{c}\text { Passive } \\
\text { Strategies (A) }\end{array}$ & $\begin{array}{c}\text { Regulatory } \\
\text { Nominal } \\
\text { Conditions (B) }\end{array}$ & $\begin{array}{l}\text { Variation } \\
\text { (A-B)/B }\end{array}$ & $\begin{array}{l}\text { Occupancy } \\
\text { Comfort (C) }\end{array}$ & $\begin{array}{c}\text { Variation } \\
(A-C) / C\end{array}$ \\
\hline \multirow{3}{*}{ Melgaço I3V1 } & Heating & 1514.87 & 2230.23 & $-32.1 \%$ & 1915.28 & $-20.9 \%$ \\
\hline & Cooling & 45.69 & 189.24 & $-75.9 \%$ & 30.93 & $47.7 \%$ \\
\hline & HVAC & 1560.56 & 2419.47 & $-35.5 \%$ & 1946.21 & $-19.8 \%$ \\
\hline \multirow{3}{*}{ Guarda I3V2 } & Heating & 1353.46 & 2058.74 & $-34.3 \%$ & 1755.28 & $-22.9 \%$ \\
\hline & Cooling & 214.78 & 511.95 & $-58.0 \%$ & 176.68 & $21.6 \%$ \\
\hline & HVAC & 1568.24 & 2570.69 & $-39.0 \%$ & 1931.96 & $-18.8 \%$ \\
\hline \multirow{3}{*}{ Portalegre I2V3 } & Heating & 625.08 & 740.45 & $-15.6 \%$ & 621.50 & $0.6 \%$ \\
\hline & Cooling & 826.91 & 1869.80 & $-55.8 \%$ & 984.30 & $-16.0 \%$ \\
\hline & HVAC & 1451.99 & 2610.25 & $-44.4 \%$ & 1605.80 & $-9.6 \%$ \\
\hline
\end{tabular}

With the implementation of passive strategies and the HVAC system used only during occupancy hours, the results show a reduction in the HVAC energy consumption that varies from $35 \%$ to more than $44 \%$ compared to the use in regulatory nominal conditions, before the passive measures. Comparing this to the results before the passive strategies but also using HVAC only during occupancy hours ("Occupancy comfort", in Table 10), it is possible to observe a reduction in heating energy consumption of more than $20 \%$, in Melgaço and Guarda, which, even with an increased consumption for cooling, generates total savings of almost $20 \%$ in both cases. In Portalegre, the energy consumption for cooling has a reduction of $16 \%$, just by applying simple passive measures. Total savings are of almost $10 \%$.

Table 11 shows, for the several studied scenarios, the percentage of useful energy needs for heating, cooling and DHW that is supplied by local renewable energy sources.

Table 11. Percentage of the useful energy needs for heating, cooling and DHW that is supplied by local renewable energy sources.

\begin{tabular}{cccc}
\hline Location & Regulatory Nominal Conditions & Realistic HVAC Schedule & Occupancy Comfort \\
\hline $\begin{array}{c}\text { Porto } \\
\text { I1V2 }\end{array}$ & $74.2 \%$ & $74.7 \%$ & $74.5 \%$ \\
\hline $\begin{array}{c}\text { Lisboa } \\
\text { I1V3 }\end{array}$ & $73.7 \%$ & $75.0 \%$ & $74.3 \%$ \\
\hline $\begin{array}{c}\text { Batalha } \\
\text { I2V1 }\end{array}$ & $75.1 \%$ & $75.8 \%$ & $75.4 \%$ \\
\hline $\begin{array}{c}\text { Viseu } \\
\text { I2V2 }\end{array}$ & $74.7 \%$ & $75.7 \%$ & $75.2 \%$ \\
\hline $\begin{array}{c}\text { Prtalegre } \\
\text { I2V3 }\end{array}$ & $72.9 \%$ & $73.6 \%$ & $73.2 \%$ \\
\hline $\begin{array}{c}\text { Melgaço } \\
\text { I3V1 }\end{array}$ & $73.5 \%$ & $73.5 \%$ & $73.5 \%$ \\
\hline $\begin{array}{c}\text { Guarda } \\
\text { I3V2 }\end{array}$ & $72.5 \%$ & $72.2 \%$ & $72.5 \%$ \\
\hline $\begin{array}{c}\text { I3V3 } \\
\text { Macedovaleiros }\end{array}$ & $73.3 \%$ & $73.4 \%$ & $73.4 \%$ \\
\hline
\end{tabular}




\section{Discussion}

The first point to discuss is the impact of minimum nZEB requirements on the construction solutions. As shown by the results, the standard dwelling, in seven of the eight analyzed locations, would not comply with nZEB first condition $\left(\mathrm{N}_{\mathrm{ic}} / \mathrm{N}_{\mathrm{i}} \leq 75 \%\right)$ if it complied only with the minimum regulatory requirements for the maximum allowable U-values. $\mathrm{N}_{\mathrm{ic}}$, meaning the annual nominal needs of useful energy for heating, depends mostly on the building heat exchanges by transmission through its envelope and by ventilation. A more demanding requirement on $\mathrm{N}_{\mathrm{ic}}$ leads to the need of increasing thermal insulation of the envelope elements. In Table 5, the changes needed are highlighted and in Table 6, the corresponding construction solutions are presented. Only for Lisboa, no changes were needed. For the coldest winter climate zone, the U-value of the walls changed from 0.34 to $0.24 \mathrm{~W} /\left(\mathrm{m}^{2}{ }^{\circ} \mathrm{C}\right)$, with $12 \mathrm{~cm}$ of XPS, which is a very unusual wall insulation thickness for Portugal. In some cases, also the window solutions had to change. These are welcome changes, as long as buildings are conceived and used in the right conditions in what concerns three determinant factors: thermal inertia, solar protection and ventilation. A high level of insulation may lead to an overheating problem in summer if solar gains are not limited and/or thermal mass is not available and/or ventilation is not used in a way it can contribute for cooling. The balance between these factors is critical and sensitive. Designers must be aware of this fact when nZEB standards are implemented.

Through the comparison of the results obtained with the quasi-stationary method of the regulation to the results of hourly dynamic simulations (Table 7) it is clear that the current regulatory method gives a good approximation to the simulated values, for the heating season. However, in the cooling season, it fails to express the highly variable climate conditions and it underestimates the cooling energy needs by a great margin. This point shows the need for an update of the regulatory calculation method, which will be defined soon through new ordinances, already announced in [28]. The adoption of the dynamic simulation is foreseen.

As stated before, the usage conditions of Portuguese households are far from the nominal conditions considered by the regulation. Certainly, a general regulation must define some nominal conditions and based on them, establishes the recommendable requirements. It would be difficult and even questionable to do it in any other way. However, in order to analyze the impact of those requirements in the actual use of the buildings, some different scenarios must be tested. Taking into account that a great part of Portuguese residential buildings is never heated or cooled by HVAC systems, it is important to simulate the freefloating scenario in order to estimate the actual comfort conditions and after that, absolute priority should be given to passive strategies and to local renewable energy sources that could fulfill the remaining energy needs.

The degree-hours of discomfort in free-floating regime, without any use of the HVAC system, leads to high levels of discomfort, especially in the harshest climates in the country (Figure 3). Cold-induced discomfort is prevailing especially in I3 climate zone but for some of the analyzed locations, like Lisboa and mostly Portalegre, the heat-induced discomfort is dominant.

In a second step of the analysis, a different possible usage profile was considered, with the use of heating in a certain period of the day, in winter. In summer, active cooling was not considered, just passive cooling by reinforcing natural ventilation. This usage profile was called the realistic HVAC schedule compared to the nominal conditions of the regulation. Thus, the degree-hours of discomfort values are reduced to less than a half of the previous ones (Figure 4). However, comfort analysis must take into account occupancy. There is no real sense in providing comfort for unoccupied dwellings. Figure 4 is still analyzing discomfort for all the hours of the day and not only during periods of occupancy. Those periods are a variable factor depending on the household, for obvious reasons. However, it is evident that most dwellings are occupied especially from the end of the afternoon to the early morning of the next day and taking this into consideration, a theoretical period of occupancy was defined. Therefore, for the realistic HVAC schedule 
and for the period of occupancy, the analysis of the degree-hours of discomfort (Figure 5) finds a reduction of the values to less than a quarter of the initial ones. However, it must be noted that using the HVAC system, between 18:00 and 23:00, in the heating season, was not enough to eliminate discomfort in occupancy hours.

Arriving at this point, it became necessary to check how much energy would be necessary to eliminate discomfort in occupancy hours. A comparison between the energy consumption by HVAC in the three different scenarios (regulatory nominal conditions, realistic HVAC schedule and ensuring occupancy comfort) shows in Table 8 that ensuring occupancy comfort through the HVAC system for both heating and cooling (using natural ventilation for cooling in summer, whenever possible), presents a reduction in the energy consumption of the HVAC system that varies from $19.6 \%$ to $58 \%$, depending on the location, when compared to the nominal conditions. As expected, the scenario of realistic HVAC schedule, with HVAC working just five hours a day and only in the heating season presents a greater energy consumption reduction varying from $49 \%$ to $95 \%$.

It should also be noted that the three locations closest to the coast have lower rates of discomfort, while the other regions located further inland and that also have a higher altitude have higher levels of discomfort. To demonstrate that the designer can (and should) carry out analyses of passive strategies to reduce levels of discomfort and, consequently, energy consumption, modifications were made to the standard model in the two cases of the greatest discomfort due to cold (Melgaço and Guarda) and in the case of the greatest discomfort due to heat (Portalegre). To reduce the levels of discomfort due to the cold, the strategy used was to increase the solar gains on the south façade by increasing the glazing area, which did not represent great heat gains in summer due to the available glazing solar protection. To reduce the levels of heat-induced discomfort, a higher rate of natural ventilation and the extension of the period of use of it and of the use of solar protection were tested. A significant reduction of discomfort was achieved with these passive strategies.

The second and third nZEB conditions define a demanding frame that leads to the choice of systems that are able to benefit from local renewable energy sources. As explained before, the main criterion to define the technical systems, as well as the construction solutions, used in this study was to comply with the minimum nZEB requirements by a very short margin. Then in a building designed to reach nZEB status, a great variety of uses may occur. Some of those uses were tested. In Table 11, the percentage of renewable energy sources contribution is shown. In terms of useful energy needs for heating, cooling and DHW, that contribution goes from $72 \%$ to almost $76 \%$. This means that, depending on the type of installed technical systems, the strict compliance with the minimum nZEB requirements may lead to remarkable savings in the energy bill of the households.

\section{Conclusions}

Using the methodology of Portuguese regulation to evaluate the impact of nZEB requirements on building envelope construction solutions, among the eight analyzed locations in the different climate zones of the country, only for Lisboa no changes are needed. In Lisboa, it is possible to meet the condition $\mathrm{N}_{\mathrm{ic}} / \mathrm{N}_{\mathrm{i}} \leq 75 \%$, when complying with the current maximum allowable U-values. For the coldest regions, higher levels of thermal insulation are needed. Thus, special attention must be given to summer conditions, because of the overheating risk, particularly in regions where the coldest winter is combined with the hottest summer.

In the study carried out, it became clear that the quasi-stationary method of the regulation gives a good approximation of winter energy needs but fails to estimate summer conditions with the same accuracy. A dynamic simulation is needed.

To evaluate the impact of nZEB requirements in the actual conditions of use of the buildings, regulatory nominal conditions are not realistic. The behavior of the users is quite complex and difficult to simulate. It is driven and most of the time, limited, by the economic resources of the household but also by personal preferences. Thermal comfort conditions 
are not consensual. To choose between ensuring comfort during the entire occupancy period or to put on another piece of clothing, using heating during the night or not, using the cooling system or not, not using the HVAC system at all, with the possible exceptions of cold or heat waves, these are very individualized options for each household. On one side, there is the need to control the expenses and on the other side, there are comfort conditions considered appropriate by the users. Thus, different usage conditions were established. With no heating or cooling, there can be high levels of discomfort especially in the most severe winter climate zone (I3) and a considerable heat-induced discomfort in some locations of the most severe summer climate zone (V3).

With five hours per day of heating, during heating season and an increase of natural ventilation for cooling in summer, it is possible to halve the number of degree-hours of discomfort. The building envelope that complies with nZEB requirements offers the opportunity to obtain thermal comfort with low energy consumption, particularly, when also high-performance technical systems are in place. In regions with a harsher climate, both with greater discomfort in summer (Portalegre), and with greater discomfort in winter (Melgaço and Guarda), it was possible to obtain a reduction in the degree-hours of discomfort and, consequently, in the energy consumption of the HVAC system through passive solutions. The solutions presented served only as an example of the possibility of reducing discomfort and energy needs. If the remaining energy needs are supplied by renewable energy sources, then energy poverty can be significantly minimized, and an enhanced quality of life will be provided to the most vulnerable population.

The regulatory role of government agencies is to ensure, through regulatory limits and incentives, that the built stock is as efficient as possible within the climate conditions of each region, to ensure a minimum level of comfort to the population and to reduce the rates of energy poverty. In this, local renewable energy sources have an important role to play. As this study proved, a strict compliance with the minimum nZEB requirements is enough for the building to benefit from a high percentage of local renewable energy, which may be almost free of costs for the users.

Author Contributions: Both authors contributed equally to the preparation of this manuscript. All authors have read and agreed to the published version of the manuscript.

Funding: This research was supported by the Base Funding UIDB/04708/2020 of CONSTRUCTInstituto de I\&D em Estruturas e Construções, funded by national funds through FCT/MCTES (PIDDAC).

Data Availability Statement: Not applicable.

Conflicts of Interest: The authors declare no conflict of interest.

\section{References}

1. European Parliament and the Council of the European Union Directive 2010/31/EU. Off. J. Eur. Union 2010, L153, 13-35.

2. European Parliament and the Council Directive (EU) 2018/844. Off. J. Eur. Union 2018, L 156, 75-91.

3. Ali, K.A.; Ahmad, M.I.; Yusup, Y. Issues, impacts, and mitigations of carbon dioxide emissions in the building sector. Sustainability 2020, 12, 7427.

4. European Commission Guidelines for the promotion of nearly zero-energy buildings and best practices to ensure that, by 2020, all new buildings are nearly zero-energy buildings-Commission Recommendation (EU) 2016/1318. Off. J. Eur. Union 2016, 208, 46-57.

5. Attia, S.; Eleftheriou, P.; Xeni, F.; Morlot, R.; Ménézo, C.; Kostopoulos, V.; Betsi, M.; Kalaitzoglou, I.; Pagliano, L.; Cellura, M.; et al. Overview and future challenges of nearly zero energy buildings (nZEB) design in Southern Europe. Energy Build. 2017, 155, 439-458. [CrossRef]

6. Belussi, L.; Barozzi, B.; Bellazzi, A.; Danza, L.; Devitofrancesco, A.; Fanciulli, C.; Ghellere, M.; Guazzi, G.; Meroni, I.; Salamone, F.; et al. A review of performance of zero energy buildings and energy efficiency solutions. J. Build. Eng. 2019, 25, 100772. [CrossRef]

7. International Energy Agency. The Future of Cooling; OECD: Paris, France, 2018; ISBN 9789264301993.

8. Santamouris, M. Cooling the buildings-past, present and future. Energy Build. 2016, 128, 617-638. [CrossRef]

9. Pajek, L.; Košir, M. Implications of present and upcoming changes in bioclimatic potential for energy performance of residential buildings. Build. Environ. 2018, 127, 157-172. [CrossRef] 
10. Eurostat Inability to Keep Home Adequately Warm-EU-SILC Survey. Available online: https:/ / appsso.eurostat.ec.europa.eu/ nui/show.do?dataset=ilc_mdes01\&lang=en (accessed on 5 March 2021).

11. Ministério da Economia e do Emprego. Decreto-Lei n. 118/2013; Diário da República n. 159/2013, Série I de 2013-08-20: Portugal, Portugal, 2013; pp. 4988-5005.

12. Ministério do Ambiente Ordenamento do Território e Energia Portaria n. ${ }^{\circ} 379-\mathrm{A} / 2015$ 2015. Available online: https:/ /data.dre. pt/web/guest/pesquisa/-/search/70789581/details/maximized (accessed on 6 February 2021).

13. Ambiente e Transição Energética. Portaria n. ${ }^{\circ}$ 98/2019; 2019. Available online: https://dre.pt/home/-/dre/121854639/details / maximized (accessed on 25 October 2020).

14. Santos-Herrero, J.M.; Lopez-Guede, J.M.; Flores-Abascal, I. Modeling, simulation and control tools for nZEB: A state-of-the-art review. Renew. Sustain. Energy Rev. 2021, 142, 110851. [CrossRef]

15. Instituto Nacional de Estatística. Estatísticas da Construção e Habitação-2019; Instituto Nacional de Estatística, Ed.; INE: Lisboa, Portugal, 2020; ISBN 978-989-25-0541-1.

16. Direção Geral de Energia e Geologia Despacho (extrato) n. ${ }^{\circ}$ 15793-F/2013. Diário da Repub. 2013, $2^{\circ}$ série, 26-31. Available online: https:/ / dre.pt/web/guest/pesquisa/- / search/2975219/details/maximized?p_p_auth=iFUG9WkE (accessed on 26 October 2020).

17. Yamazaki, D.; Ikeshima, D.; Tawatari, R.; Yamaguchi, T.; O’Loughlin, F.; Neal, J.C.; Sampson, C.C.; Kanae, S.; Bates, P.D. A high-accuracy map of global terrain elevations. Geophys. Res. Lett. 2017, 44, 5844-5853. [CrossRef]

18. P3E.; Itecons Ferramentas de cálculo DL 118/2013. Available online: http:/ / www.itecons.uc.pt/p3e/index.php (accessed on 11 March 2021).

19. Direção Geral de Energia e Geologia SCE.ER-Dados e cálculos para aproveitamento de Energias Renováveis em edifícios. Available online: https:/ /www.dgeg.gov.pt/pt/areas-setoriais/energia/energias-renovaveis-e-sustentabilidade/sce-er/ (accessed on 10 March 2021).

20. Team DesignBuilder. ANSI/ASHRAE Standard 140-2017 Building Thermal Envelope and Fabric Load Tests; 2021. Available online: https: / / designbuilder.co.uk/download/documents/387-v6-1-ashrae-140-test-results (accessed on 26 June 2021).

21. Direção Geral de Energia e Geologia Despacho (extrato) n. ${ }^{\circ}$ 15793-K/2013. Diário da Repub. 2013, $2^{\circ}$ série, 30 . Available online: https://dre.pt/home/-/dre/2975224/details/maximized (accessed on 26 October 2020).

22. dos Santos, C.A.P.; Matias, L. ITE 50-Coeficientes De Transmissão Térmica De Elementos Da Envolvente Dos Edifícios; LNEC: Lisboa, Portugal, 2006.

23. REC REC Peak Energy BLK Series. Available online: https://www.renugen.co.uk/content/Solar_Panel_Brochures_part_3/Solar_ Panel_Brochures_part_3/rec_brochure/REC-Peak-Energy-BLK-REC260PE-BLK-260-Watt-Solar-Panel-Module-Brochure.pdf (accessed on 13 March 2021).

24. Baxi Bombas de calor AQS BC ACS 180/230. Available online: https://mediacdn.baxi.pt/-/media/inriver-media/baxi-iberiamedia/2020/5/26/a00b00c02d12catalog5pt01pdf.pdf?v=1\&d=20200526T173735Z (accessed on 13 March 2021).

25. Baxi Bombas de calor AQS BC ACS 200/300. Available online: https:/ /www.baxi.pt/-/media/inriver/30562-10784.pdf (accessed on 13 March 2021).

26. Baxi Bombas de calor AQS BC ACS Split. Available online: https://www.baxi.pt/-/media/inriver/30564-10786.pdf (accessed on 13 March 2021).

27. Samsung Ar Condicionado Residencial, R32, Mural, Luzon, 2.5kW. Available online: https://www.samsung.com/pt/business/ climate/ac-rar-ar09txhzawkn/ (accessed on 13 March 2021).

28. Presidência do Conselho de Ministros. Decreto-Lei n.o 101-D/2020. Diário da República n.o 237/2020, 1o Supl. Série I de 2020-12-07: Portugal, Portugal. 2020; 21-45. 